\title{
I want to 377 you so bad*
}

\section{Akhil Katyal*}

*Correspondence: (akhilkatyal@gmail.com)

*This refers to Section 377 of the Indian Penal Code, a colonial era law that criminalises homosexual acts. In 2013, the Supreme Court of India upheld the legality of this law. LGBT activists and other human rights legal practitioners have launched several challenges to this law.

till even the sheets hurt i want to

ache your knees singe your skin

line you brown breathe you in i want to

mouth you in words neck you in red

i want to beg your body insane into sepals

i want to 377 you like a star falling off the brown

i want to feel you till my nails turn water

i want to suck you seven different skies

i want to be a squatter in your head when

it sleeps when its dark i want to break laws

with you in bed and in streets and in parks

(C) Copyright: The Authors. This article is issued under the terms of the Creative Commons Attribution NonCommercial Share Alike License, which permits use and redistribution of the work provided that the original author and source are credited, the work is not used for commercial purposes and that any derivative works are made available under the same license terms. 
Akhil Katyal is a writer and translator based in Delhi where he also teaches literature. His writings have appeared widely in national and international journals and anthologies. He has translated the works of Mangalesh Dabral, Wislawa Szymborska, Agha Shahid Ali, Om Prakash Valmiki, Dorothy Parker and Langston Hughes, among others. He finished his PhD from SOAS, University of London in 2011.

To cite this poem:

Katyal, A. (2016). I want to 377 you so bad*. Feminist Dissent, (1), 117-118. Retrieved from:

http://journals.warwick.ac.uk/index.php/feministdissent/article/view/12 